\title{
PEMODELAN INDEKS PEMBANGUNAN MANUSIA MENGGUNAKAN ANALISIS REGRESI SPASIAL DI PROVINSI JAWA TIMUR
}

\author{
MILA ROSA, MAIYASTRI, HAZMIRA YOZZA \\ Program Studi S1 Matematika, \\ Fakultas Matematika dan Ilmu Pengetahuan Alam, Universitas Andalas, \\ Kampus UNAND Limau Manis Padang, Indonesia. \\ email : milarosamila@gmail.com,maiyastri@sci.unand.ac.id,hazmirayozza@sci.unand.ac.id
}

Diterima 15 September 2020 Direvisi 14 Oktober 2020 Dipublikasikan 21 Oktober 2020

\begin{abstract}
Abstrak. Analisis regresi spasial merupakan hasil pengembangan dari metode regresi linear klasik yang dilakukan dengan mempertimbangkan adanya pengaruh lokasi atau spasial pada data yang dianalisis. Analisis regresi spasial dapat digunakan jika terdapat autokorelasi spasial antar daerah. Autokorelasi spasial tersebut dapat diukur dengan statistik uji Moran's I. Pada penelitian ini akan dibentuk model untuk menentukan faktor-faktor yang mempengaruhi Indeks Pembangunan Manusia (IPM) menurut kabupaten/kota di Provinsi Jawa Timur dengan menggunakan analisis regresi spasial. Berdasarkan pengujian menggunakan statistik uji Moran's I diperoleh bahwa pada data Indeks Pembangunan Manusia (IPM) terdapat autokorelasi positif. Selanjutnya dilakukan analisis regresi spasial menggunakan Spatial Autoregressive Model (SAR) dengan parameter $\rho=0,00001$. Hal ini menunjukkan bahwa terdapat hubungan antara masingmasing lokasi. Hasil analisis menunjukkan bahwa variabel bebas yang mempengaruhi Indeks Pembangunan Manusia (IPM) di Provinsi Jawa Timur adalah persentase penduduk miskin, persentase rumah tangga yang memiliki tempat buang air besar sendiri dan persentase kepadatan penduduk.
\end{abstract}

Kata Kunci: Autokorelasi spasial, Uji Moran's I, Spatial Autoregressive Model

\section{Pendahuluan}

Indeks Pembangunan Manusia (IPM) merupakan suatu indeks komposit yang terangkum dari pendekatan tiga dimensi dasar manusia, meliputi umur panjang dan sehat (sebagai ukuran longevity), pengetahuan/pendidikan (sebagai ukuran knowledge), dan standar hidup layak atau tingkat pendapatan riil (sebagai ukuran living standars). Laporan tahunan UNDP pada tahun 2019 mengkonfirmasi bahwa IPM Indonesia membaik dibanding tahun sebelumnya yaitu berada pada peringkat 111/189 negara. Hal ini menunjukkan masih diperlukannya upaya untuk memperbaiki kualitas manusia di Indonesia di tengah-tengah persaingan dengan masyarakat

*penulis korespondensi 
internasional. Upaya peningkatan IPM Indonesia tentunya tidak dapat dilepaskan dari usaha simultan untuk meningkatkan IPM kabupaten/kota di Indonesia, termasuk di Provinsi Jawa Timur.

Indeks Pembangunan Manusia (IPM) di suatu kabupaten/kota tidak lepas dari pengaruh Indeks Pembangunan Manusia (IPM) di kabupaten/kota yang berdekatan. Hal ini mengindikasikan adanya faktor lokasi (spasial). Adanya faktor spasial yang terjadi akan menyebabkan data antar pengamatan sulit untuk memenuhi asumsi regresi linier klasik yaitu asumsi saling bebas (independent), sehingga pemodelan Indeks Pembangunan Manusia (IPM) dapat diselesaikan dengan menggunakan analisis regresi spasial.

\section{Landasan Teori}

Data spasial mempunyai pengertian sebagai suatu data yang mengacu pada posisi, obyek dan hubungan diantaranya dalam ruang bumi atau bisa dikatakan data yang berkaitan dengan lokasi.

\subsection{Matriks Contiguity dan Matriks Pembobot Spasial}

Matriks contiguity $\boldsymbol{C}=\left[c_{i j}\right]$ menunjukkan hubungan spasial suatu lokasi dengan lokasi lainnya yang bertetangga, dimana $c_{i j}=1$ jika lokasi- $i$ bertetangga dengan lokasi- $j$ dan $c_{i j}=0$ jika lokasi- $i$ tidak bertetangga dengan lokasi- $j$. Terdapat tiga tipe matriks contiguity berdasarkan tipe interaksi atau persinggungan batas wilayah, yaitu $[4]$ :

(1) Rock Contiguity.

Rock contiguity ialah persentuhan sisi wilayah satu dengan sisi wilayah lain yang bertetangga.

(2) Bishop Contiguity.

Bishop contiguity ialah persentuhan titik sudut wilayah satu dengan wilayah lain yang bertetangga.

(3) Queen Contiguity.

Queen contiguity ialah persentuhan sisi maupun titik sudut wilayah satu dengan wilayah yang lain yaitu gabungan rook contiguity dan bishop contiguity.

Matriks pembobot spasial $\boldsymbol{W}=\left[w_{i j}\right]$ merupakan matriks yang menyatakan hubungan dari wilayah pengamatan yang berukuran $n \times n$, dimana $w_{i j}>0$ jika wilayah $i$ dan $j$ berdekatan dan $w_{i j}=0$ jika wilayah $i$ dan $j$ tidak berdekatan.

Unsur dari matriks pembobot spasial pada baris ke- $i$ dan kolom ke- $j$ adalah $w_{i j}$ yang dapat dirumuskan dengan [4]

$$
w_{i j}=\frac{c_{i j}}{\sum_{i=1}^{n} c_{i j}} .
$$

\subsection{Moran's I}

Autokorelasi spasial terjadi akibat adanya autokorelasi dalam data wilayah. Adanya autokorelasi spasial mengindikasikan bahwa nilai atribut pada daerah tertentu 
terkait oleh nilai atribut daerah lain yang letaknya berdekatan atau bertetanggaan. Salah satu cara yang dilakukan untuk mengukur autokorelasi spasial adalah dengan menggunakan Moran's I. Moran's I adalah ukuran dari korelasi (hubungan) antara pengamatan yang saling berdekatan. Moran's I dirumuskan sebagai berikut.

$$
I=\frac{n \sum_{i=1}^{n} \sum_{j=1}^{n} w_{i j}\left(y_{i}-\bar{y}\right)\left(y_{j}-\bar{y}\right)}{S_{0} \sum_{i}\left(y_{i}-\bar{y}\right)^{2}}
$$

dengan:

$w_{i j}$ : elemen matriks pembobot spasial $\boldsymbol{W}$ pada baris ke $-i$ dan kolom ke $-j$,

$y_{i}$ : nilai pengamatan pada lokasi ke $-i$,

$y_{j}:$ nilai pengamatan pada lokasi ke $-j$.

Hipotesis yang digunakan pada uji Moran's I adalah

$$
\begin{aligned}
& H_{0} \text { : tidak terdapat autokorelasi spasial antar lokasi, } \\
& H_{1} \text { : terdapat autokorelasi spasial antar lokasi. }
\end{aligned}
$$

Statistik uji yang digunakan adalah

$$
Z_{\text {hitung }}=\frac{I-E[I]}{\sqrt{\operatorname{VarI}}} .
$$

Apabila $\left|Z_{\text {hitung }}\right|>Z_{\frac{\alpha}{2}}$ maka diambil keputusan tolak $H_{0}$, artinya terdapat autokorelasi spasial antar lokasi [3].

\subsection{Analisis Regresi Spasial}

Analisis regresi spasial adalah suatu analisis yang digunakan untuk mengevaluasi hubungan antara satu variabel dengan beberapa variabel lainnya dengan memperhatikan pengaruh spasial (lokasi).

Model umum regresi spasial adalah sebagai berikut [1] :

$$
\boldsymbol{Y}=\rho \boldsymbol{W} \boldsymbol{y}+\boldsymbol{X} \boldsymbol{\beta}+\boldsymbol{u}
$$

dengan

$$
\boldsymbol{u}=\lambda \boldsymbol{W} \boldsymbol{u}+\varepsilon
$$

Analisis regresi spasial terdiri dari :

(1) Model Regresi Spasial Lag.

Model regresi spasial lag atau Spatial Autoregressive (SAR) adalah suatu model linear dimana terdapat korelasi spasial pada variabel terikatnya. Model SAR dapat dituliskan sebagai [1]

$$
\boldsymbol{Y}=\rho \boldsymbol{W} \boldsymbol{y}+\boldsymbol{X} \boldsymbol{\beta}+\boldsymbol{\varepsilon}
$$

Untuk data sampel, model pada Persamaan (2.5) dapat dituliskan sebagai

$$
\boldsymbol{Y}=\rho \boldsymbol{W} \boldsymbol{y}+\boldsymbol{X} \boldsymbol{b}+\boldsymbol{e}
$$

Adapun penduga parameter dari dari model regresi SAR, yaitu sebagai berikut :

$$
\boldsymbol{b}=\left(\boldsymbol{X}^{\boldsymbol{T}} \boldsymbol{X}\right)^{-1} \boldsymbol{X}^{T}(\boldsymbol{I}-\rho \boldsymbol{W}) \boldsymbol{Y}
$$


(2) Model Regresi Spasial Error.

Model regresi spasial error atau Spatial Error Model (SEM) merupakan suatu model regresi linear yang pada galatnya terdapat korelasi spasial [5]. Bentuk umum persamaan Spatial Error Model (SEM) adalah sebagai berikut.

$$
\boldsymbol{Y}=\boldsymbol{X} \boldsymbol{\beta}+\boldsymbol{u}
$$

dengan

$$
\boldsymbol{u}=\lambda \boldsymbol{W} \boldsymbol{u}+\boldsymbol{\varepsilon} .
$$

Dari Persamaan (2.8) dan (2.9) dapat ditulis bentuk umum untuk Spatial Error Model (SEM) menjadi

$$
\boldsymbol{Y}=\boldsymbol{X} \boldsymbol{\beta}+\lambda \boldsymbol{W} \boldsymbol{u}+\boldsymbol{\varepsilon} .
$$

Untuk data sampel, model pada Persamaan (2.8) dan (2.9) dapat dituliskan sebagai

$$
\boldsymbol{Y}=\boldsymbol{X} \boldsymbol{b}+\boldsymbol{u}
$$

dengan

$$
\boldsymbol{u}=\lambda \boldsymbol{W} \boldsymbol{u}+\boldsymbol{e} .
$$

Adapun penduga parameter dari model regresi SEM yaitu sebagai berikut :

$$
\boldsymbol{b}=\left[(\boldsymbol{X}-\lambda \boldsymbol{W} \boldsymbol{X})^{T}(\boldsymbol{X}-\lambda \boldsymbol{W} \boldsymbol{X})\right]^{-1}(\boldsymbol{X}-\lambda \boldsymbol{W} \boldsymbol{X})^{T}(\boldsymbol{Y}-\lambda \boldsymbol{W} \boldsymbol{Y}) .
$$

\subsection{Uji Lagrange Multiplier (LM)}

Uji Lagrange Multiplier digunakan sebagai dasar untuk memilih model regresi spasial yang sesuai [5].

(1) Uji Lagrange Multiplier Lag.

Uji Lagrange Multiplier Lag dapat digunakan untuk mengidentifikasi ada atau tidaknya autokorelasi spasial lag pada variabel terikat. Hipotesis pengujian yang digunakan pada uji ini adalah

$H_{0}: \rho=0$ ( tidak terdapat ketergantungan spasial lag pada variabel terikat), $H_{1}: \rho \neq 0$ ( terdapat ketergantungan spasial lag pada variabel terikat).

Statistik uji yang digunakan adalah:

$$
L M_{l a g}=\frac{\left[\varepsilon^{T} \boldsymbol{W} \boldsymbol{Y}\right]^{2}}{\left[\varepsilon^{T} \boldsymbol{\varepsilon} / n\right]^{2} D} .
$$

Apabila $L M_{l a g}>\chi_{(\alpha, 1)}^{2}$ atau jika $p-$ value $<\alpha$ maka diambil keputusan untuk tolak $H_{0}$ yang artinya pada taraf nyata $\alpha$ disimpulkan bahwa terdapat ketergantungan spasial lag pada variabel terikat [2] 
(2) Uji Lagrange Multiplier Error.

Uji Lagrange Multiplier Error digunakan untuk mengidentifikasi adanya autokorelasi spasial pada galat. Hipotesis pengujian yang digunakan pada uji ini adalah

$$
\begin{aligned}
& H_{0}: \lambda=0 \text { ( tidak terdapat ketergantungan spasial pada galat), } \\
& H_{1}: \lambda \neq 0 \text { ( terdapat ketergantungan spasial pada galat). }
\end{aligned}
$$

Statistik uji yang digunakan adalah:

$$
L M_{\text {error }}=\frac{\left[\varepsilon^{T} \boldsymbol{W} \boldsymbol{Y}\right]^{2}}{\left[\varepsilon^{\boldsymbol{T}} \varepsilon / n\right]^{2} \operatorname{tr}\left(\boldsymbol{W}^{\boldsymbol{T}} \boldsymbol{W}+\boldsymbol{W} \boldsymbol{W}\right)} .
$$

Apabila $L M_{\text {error }}>\chi_{(\alpha, 1)}^{2}$ atau jika $p-$ value $<\alpha$ maka diambil keputusan tolak $H_{0}$ yang artinya pada taraf nyata $\alpha$ disimpulkan bahwa terdapat ketergantungan spasial pada galat [2].

\section{Metode Penelitian}

Data yang digunakan pada penelitian ini merupakan data Indeks Pembangunan Manusia (IPM) untuk kabupaten/kota yang ada di Provinsi Jawa Timur pada tahun 2019 beserta data faktor-faktor yang diduga mempengaruhi Indeks Pembangunan Manusia (IPM) di antaranya persentase penduduk miskin, persentase rumah tangga yang memiliki tempat buang air besar sendiri, kepadatan penduduk dan persentase rumah tangga yang memiliki lantai tanah. Semua data ini diperoleh dari website Badan Pusat Statistik (BPS) Jawa Timur. Adapun variabel-variabel yang digunakan adalah:

(1) Variabel Terikat.

Variabel terikat yang digunakan dalam penelitian ini adalah Indeks Pembangunan Manusia (IPM) untuk kabupaten/kota yang ada di Jawa Timur tahun 2019.

(2) Variabel Bebas.

Variabel bebas yang digunakan pada penelitian ini sebanyak 4 variabel bebas yaitu:

$X_{1}$ : persentase penduduk miskin,

$X_{2}$ : persentase rumah tangga yang memiliki tempat buang air besar sendiri,

$X_{3}$ : kepadatan penduduk,

$X_{4}$ : persentase rumah tangga yang memiliki lantai tanah.

Langkah-langkah analisis data yang dilakukan dalam penelitian ini adalah sebagai berikut.

(1) Melakukan analisis deskriptif terhadap semua variabel yang terlibat.

(2) Menentukan model regresi linier klasik dengan metode kuadrat terkecil atau Ordinary Least Square (OLS).

(3) Melakukan uji asumsi klasik yang harus dipenuhi seperti uji normalitas, uji homoskedastisitas dan uji autokorekasi. 
(4) Menghitung koefisien autokorelasi spasial serta menguji signifikansinya untuk memeriksa apakah terdapat autokorelasi spasial menggunakan uji Moran's I.

(5) Melakukan uji Lagrange Multiplier untuk memilih model regresi spasial yang sesuai.

(6) Menampilkan model yang terpilih dari uji Lagrange Multiplier yang dilakukan

(7) Melakukan uji signifikansi parameter regresi spasial.

(8) Memberikan interpretasi terhadap model regresi spasial yang diperoleh.

\section{Pembahasan}

\subsection{Deskripsi Data}

Analisis deskriptif pada data penelitian dilakukan dengan membentuk diagram pencar yang akan memperlihatkan hubungan antara Indeks Pembangunan Manusia (IPM) dengan variabel bebas yang diduga dapat mempengaruhi Indeks Pembangunan Manusia (IPM) di antaranya persentase penduduk miskin, persentase rumah tangga yang memiliki tempat buang air besar sendiri, kepadatan penduduk dan persentase rumah tangga yang memiliki lantai tanah.

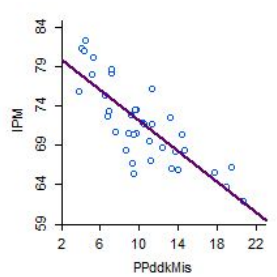

Gambar 1

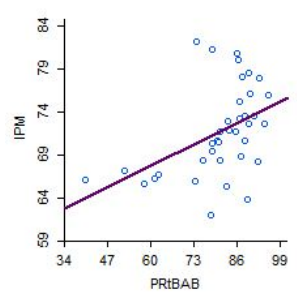

Gambar 2

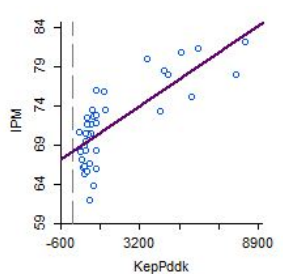

Gambar 3

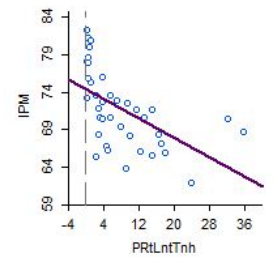

Gambar 4

Gambar 1 memperlihatkan hubungan antara IPM dengan persentase penduduk miskin. Pada Gambar 1 diperoleh nilai koefisien korelasinya sebesar -0,808. Nilai koefisien korelasi yang didapatkan bernilai negatif, artinya semakin tinggi persentase penduduk miskin maka semakin rendah IPM di daerah tersebut.

Gambar 2 memperlihatkan hubungan antara IPM dengan persentase rumah tangga yang memiliki tempat buang air besar sendiri. Pada Gambar 2 diperoleh nilai koefisien korelasinya sebesar 0,446. Nilai koefisien korelasi yang didapatkan bernilai positif. Ini berarti, semakin tinggi persentase rumah tangga yang memiliki tempat buang air besar sendiri maka semakin tinggi IPM di daerah tersebut.

Gambar 3 memperlihatkan hubungan antara IPM dengan kepadatan penduduk. Pada Gambar 3 diperoleh nilai koefisien korelasinya sebesar 0,773. Nilai koefisien korelasi yang didapatkan bernilai positif. Ini berarti, semakin luas kepadatan penduduk maka semakin tinggi IPM di daerah tersebut.

Gambar 4 memperlihatkan hubungan antara IPM dengan persentase rumah tangga yang memiliki lantai tanah. Pada Gambar 4 diperoleh nilai koefisien korelasinya $-0,552$. Nilai koefisien korelasi yang didapatkan bernilai negatif, artinya semakin tinggi persentase rumah tangga yang memiliki lantai tanah maka semakin rendah IPM di daerah tersebut. 


\subsection{Autokorelasi Spasial}

Untuk memeriksa ada atau tidaknya autokorelasi spasial digunakan nilai Moran's I yang selanjutnya akan diuji signifikansinya pada tingkat kesalahan adalah 0,05. Sebelum melakukan hal tersebut terlebih dahulu ditentukan matriks pembobot spasial.

\subsubsection{Matriks Pembobot Spasial}

Pada penelitian ini, matriks pembobot spasial yang dibuat menggunakan tipe interaksi atau persinggungan sisi maupun titik sudut wilayah satu dengan wilayah yang lain atau disebut dengan Queen Contiguity.

\subsubsection{Uji Morans'I}

Pemeriksaan autokorelasi spasial menggunakan perhitungan uji Moran's I merupakan teknik analisis spasial untuk mengetahui ada atau tidaknya hubungan autokorelasi spasial antar lokasi pengamatan.

Diperoleh nilai statistik uji Moran's I

$$
Z_{\text {hitung }}=\frac{I-E[I]}{\sqrt{\operatorname{VarI}}}=\frac{0,4560-(-0,027)}{\sqrt{0,0170}}=3,703 .
$$

Berdasarkan perhitungan statistik uji diperoleh $Z_{\text {hitung }}=3,703>1,96=Z_{\alpha / 2}$, maka diambil keputusan tolak $H_{0}$ yang berarti bahwa terdapat autokorelasi spasial pada data Indeks Pembangunan Manusia (IPM) di kabupaten/kota Provinsi Jawa Timur pada tahun 2019.

\subsection{Model Regresi Spasial}

Selanjutnya akan dibentuk model regresi spasial yang didahului dengan melakukan uji Lagrange Multiplier dan melakukan uji signifikansi parameter regresi spasial. Tabel berikut ini menunjukkan hasil uji Lagrange Multiplier.

Tabel 1. Hasil Uji Ketergantungan Spasial dengan Uji LM

\begin{tabular}{|l|c|c|c|}
\hline Jenis Statistik Uji & Nilai Uji LM & Nilai p-value & Tingkat Kesalahan $(\alpha)$ \\
\hline LM Lag & 13,3848 & 0,00025 & 0,05 \\
\hline LM Error & 2,4575 & 0,11696 & 0,05 \\
\hline
\end{tabular}

Dari uji $L M_{l a g}$ diperoleh nilai $p$-value sebesar $0,00025<\alpha=0,05$ sehingga dapat diambil keputusan tolak $H_{0}$. Ini berarti bahwa pada taraf nyata 0,05 disimpulkan bahwa terdapat ketergantungan spasial lag pada variabel terikat. Pada uji $L M_{\text {error }}$ diperoleh nilai $p$-value sebesar 0,11696> $>\alpha=0,05$ sehingga dapat diambil keputusan tidak tolak $H_{0}$. Ini berarti bahwa pada taraf nyata 0,05 disimpulkan bahwa tidak terdapat ketergantungan spasial pada galat model.

Selanjutnya akan dilakukan uji signifikansi parameter model spasial lag. Tabel berikut ini menunjukkan hasil output regresi spasial lag 
Tabel 2. Hasil Pendugaan Parameter Regresi Spasial Lag atau Spatial Autoregressive Model (SAR)

\begin{tabular}{|c|c|c|c|c|}
\hline Variabel & Koefisien & Std. Error & Z- Statistik & $\boldsymbol{p}$-value \\
\hline$\rho$ & 0,423868 & 0,0962952 & 4,40176 & 0,00001 \\
\hline Konstanta & 39,711 & 7,17735 & 5,53282 & 0,00000 \\
\hline$X_{1}$ & $-0,395905$ & 0,10705 & $-3,69832$ & 0,00022 \\
\hline$X_{2}$ & 0,0535524 & 0,0269736 & 1,98536 & 0,04710 \\
\hline$X_{3}$ & 0,0010339 & 0,000174296 & 5,93185 & 0.00000 \\
\hline$X_{4}$ & $-0,0138866$ & 0,0441071 & $-0,314838$ & 0,75288 \\
\hline
\end{tabular}

Dari Tabel 2 dapat dilihat bahwa semua variabel bebas yang diduga terkait dengan IPM tidak semuanya memberikan pengaruh yang signifikan terhadap IPM. Ini dapat dilihat dari nilai $p$-value yang diperoleh. Jika pada pengujian hipotesis diperoleh $p$-value $<\alpha$ maka dapat disimpulkan bahwa variabel bebas memberikan pengaruh yang signifikan terhadap IPM dan sebaliknya. Ini berarti, variabel bebas persentase penduduk miskin $\left(X_{1}\right)$, persentase rumah tangga yang memiliki tempat buang air besar sendiri $\left(X_{2}\right)$ dan kepadatan penduduk $\left(X_{3}\right)$ memberikan pengaruh yang signifikan terhadap variabel terikat IPM karena memiliki nilai $p$-value lebih kecil dari $\alpha=0,05$. Untuk variabel bebas persentase rumah tangga yang memiliki lantai tanah $\left(X_{4}\right)$ tidak memberikan pengaruh yang signifikan terhadap variabel terikat karena memiliki nilai $p$-value lebih besar dari $\alpha=0,05$.

Tahapan selanjutnya adalah membentuk kembali model regresi spasial lag dengan variabel bebas yang signifikan terhadap variabel terikat Indeks Pembangunan Manusia (IPM) di Provinsi Jawa Timur. Berikut hasil pendugaan parameter regresi spasial lag dengan variabel bebas yang signifikan.

Tabel 3. Hasil Pendugaan Parameter Regresi Spasial Lag dengan Variabel Bebas Signifikan

\begin{tabular}{|c|c|c|c|c|}
\hline Variabel & Koefisien & Std. Error & Z- Statistik & $\boldsymbol{p}$-value \\
\hline$\rho$ & 0,421028 & 0,0963855 & 4,36816 & 0,00001 \\
\hline Konstanta & 39,9038 & 7,16783 & 5,56707 & 0,00000 \\
\hline$X_{1}$ & $-0,411521$ & 0,0968086 & $-4,25087$ & 0,00002 \\
\hline$X_{2}$ & 0,0540385 & 0,0270412 & 1,99838 & 0,04568 \\
\hline$X_{3}$ & 0,00104268 & 0,000172331 & 6,05043 & 0,00000 \\
\hline
\end{tabular}

Dari Tabel 3 semua variabel bebas memberikan nilai $p$-value yang lebih kecil dai $\alpha=0,05$. Ini berarti bahwa persentase penduduk miskin $\left(X_{1}\right)$, persentase rumah tangga yang memiliki tempat buang air besar sendiri $\left(X_{2}\right)$ dan kepadatan penduduk $\left(X_{3}\right)$ memberikan pengaruh yang signifikan terhadap variabel terikat 
IPM di Provinsi Jawa Timur tahun 2019. Selanjutnya, dapat dilihat juga bahwa koefisien ketetanggaan antar lokasi $(\rho)$ juga berpengaruh signifikan dimana nilai $p$-value yang diperoleh sebesar $0,00001<0,05=\alpha$. Hal ini menunjukkan bahwa terdapat hubungan antara masing-masing lokasi.

\subsection{Interpretasi Model}

Pada penelitian ini, diperoleh model regresi spasial lag atau Spatial Autoregressive Model (SAR) sebagai berikut

$$
Y=39,9038+0,421028 \boldsymbol{W} \boldsymbol{y}-0,411521 X_{1}+0.0540385 X_{2}+0.00104268 X_{3}
$$

Model regresi spasial lag atau Spatial Autoregressive Model (SAR) di atas dapat diinterpretasikan bahwa variabel persentase penduduk miskin $\left(X_{1}\right)$ berhubungan negatif yang signifikan terhadap Indeks Pembangunan Manusia (IPM). Koefisien regresi persentase penduduk miskin $\left(X_{1}\right)$ sebesar -0,411521. Artinya jika persentase penduduk miskin $\left(X_{1}\right)$ naik sebanyak 1\%, maka akan menurunkan Indeks Pembangunan Manusia (IPM) di wilayah tersebut sebanyak 0,411521 poin dengan variabel bebas lainnya dianggap konstan.

Untuk variabel persentase rumah tangga yang memiliki tempat buang air besar sendiri $\left(X_{2}\right)$ berhubungan positif yang signifikan terhadap Indeks Pembangunan Manusia (IPM) dengan koefisien regresi sebesar 0.0540385. Hal ini berarti bahwa jika persentase rumah tangga yang memiliki tempat buang air besar sendiri $\left(X_{2}\right)$ naik $1 \%$ maka akan meningkatkan Indeks Pembangunan Manusia (IPM) di wilayah tersebut sebanyak 0.0540385 poin dengan variabel bebas lainnya dianggap konstan.

Untuk variabel persentase kepadatan penduduk $\left(X_{3}\right)$ berhubungan positif yang signifikan terhadap Indeks Pembangunan Manusia (IPM) dengan koefisien regresi sebesar 0.00104268. Hal ini berarti bahwa jika kepadatan penduduk $\left(X_{3}\right)$ meluas sebanyak $1 \mathrm{~km}^{2}$ maka akan meningkatkan Indeks Pembangunan Manusia (IPM) di wilayah tersebut sebanyak 0.00104268 poin dengan variabel bebas lainnya dianggap konstan.

\section{Kesimpulan}

Pada penelitian ini dapat disimpulkan bahwa model regresi spasial lag atau Spatial Autoregressive Model (SAR) yang didapatkan pada data Indeks Pembangunan Manusia (IPM) kabupaten/kota di Provinsi Jawa Timur tahun 2019 adalah

$$
Y=39,9038+0,421028 \boldsymbol{W} \boldsymbol{y}-0,411521 X_{1}+0.0540385 X_{2}+0.00104268 X_{3} .
$$

Ini menunjukkan persentase rumah tangga yang memiliki tempat buang air besar sendiri $\left(X_{2}\right)$ dan kepadatan penduduk $\left(X_{3}\right)$ memiliki pengaruh untuk meningkatkan Indeks Pembangunan Manusia (IPM), sedangkan persentase penduduk miskin $\left(X_{1}\right)$ memiliki pengaruh untuk menurunkan Indeks Pembangunan Manusia (IPM). 
356 Mila Rosa, dkk

\section{Ucapan Terima Kasih}

Penulis mengucapkan terima kasih kepada bapak Dr. Dodi Devianto, ibu Izzati Rahmi HG, M.Si dan bapak Prof. Dr. Muhafzan yang telah memberikan masukan dan saran sehingga makalah ini dapat diselesaikan dengan baik.

\section{Daftar Pustaka}

[1] Anselin, L. 1988. Spatial Econometrics: Methods and Models. Kluwer Academic, Dordrecht

[2] Anselin, L. 2009. Spatial Regression. Editor : Fotheringham AS, PA Rogerson Handbook of Spatial Analysis. Sage Publication, London

[3] Lee, J. dan D.W.S. Wong. 2001. Statistical Analysis with ArcView GIS. John Wiley \& Sons Inc, New York

[4] LeSage, J.P. 1999. The Theory and Practice of Spatial Econometrics. Department of Economics University of Toledo, Toledo

[5] LeSage, J.P dan R.K. Pace. 2009. Introduction to Spatial Econometrics. CRC Press, Texas State University San Marcos 